\title{
Author Correction: TRPC5 channels participate in pressure-sensing in aortic baroreceptors
}

\author{
On-Chai Lau, Bing Shen, Ching-On Wong, Yung-Wui Tjong, Chun-Yin Lo, Hui-Chuan Wang, Yu Huang, \\ Wing-Ho Yung, Yang-Chao Chen, Man-Lung Fung, John Anthony Rudd \& Xiaoqiang Yao
}

Nature Communications 7:11947 doi: 10.1038/ncomms11947 (2016); Published online 14 Jul 2016; Updated 23 Mar 2018

It has come to our attention that errors were made in measurements of resting blood pressure reported in this article, in Fig. 8 and in the 'Results' section entitled 'Deficiency of baroreceptor function in Trpc5 knockout (Trpc5 $5^{-/}$) mice'. Two of the twelve measurements for $\operatorname{Trpc5} 5^{-/-}$mice exceeded physiologically realistic values $(277.3$ and $390.5 \mathrm{~mm} \mathrm{Hg})$, and we assume were a result of technical errors in blood pressure recording. Upon removal of these two outliers and their corresponding control measurements, and replacement with resting blood pressure measurements from two additional pairs of mice, we no longer find a statistically significant difference in the resting mean arterial pressure between $\operatorname{Trpc5} 5^{-/-}$and wild-type mice $\left(121 \pm 8 \mathrm{~mm} \mathrm{Hg}, n=12\right.$ for Trpc5 $5^{-/-}$mice versus $105 \pm 4 \mathrm{~mm} \mathrm{Hg}, n=12$ for wild-type mice, $P>0.05$ by Student's $t$-test). We can therefore no longer conclude that Trpc5 knockout increases basal blood pressure. However, a statistically significant difference in range of blood pressure variation over $24 \mathrm{~h}$ remains $\left(60 \pm 6 \mathrm{~mm} \mathrm{Hg}, n=12\right.$ for wild-type mice and $114 \pm 22 \mathrm{~mm} \mathrm{Hg}, n=12$ for $\operatorname{Trpc} 5^{-/-}$mice, $P<0.05$ by Student's $t$-test). These errors therefore do not affect our conclusion that $\operatorname{Trpc5}$ knockout results in blood pressure instability.

An updated version of Fig. 8d, which includes the above data, is presented below as Fig. 1. The error has not been corrected in the original version of the Article. Furthermore all resting mean arterial blood pressure data from the two mouse cohorts are presented as Supplementary Data 1 associated with this Author Correction.

We thank Pratish Thakore, Prof Susan Brian and Prof David Beech for their Correspondence, which highlights this issue ${ }^{1}$. In an associated Reply, we also respond in more detail to the criticisms raised ${ }^{2}$.

1. Thakore, P., Brain, S. D. \& Beech, D. J. Challenging a proposed role for TRPC5 in aortic baroreceptor pressure-sensing. Nat. Commun. https://doi.org/10.1038/s41467-017-02703-w (2018).

2. Lau, O.-C. et al. Reply to 'Challenging a proposed role for TRPC5 in aortic baroreceptor pressure-sensing'. Nat. Commun. https://doi.org/10.1038/s41467-017-02704-9 (2018).

Open Access This article is licensed under a Creative Commons Attribution 4.0 International License, which permits use, sharing, adaptation, distribution and reproduction in any medium or format, as long as you give appropriate credit to the original author(s) and the source, provide a link to the Creative Commons license, and indicate if changes were made. The images or other third party material in this article are included in the article's Creative Commons license, unless indicated otherwise in a credit line to the material. If material is not included in the article's Creative Commons license and your intended use is not permitted by statutory regulation or exceeds the permitted use, you will need to obtain permission directly from the copyright holder. To view a copy of this license, visit http://creativecommons.org/licenses/by/4.0/
}

(C) The Author(s) 2018 

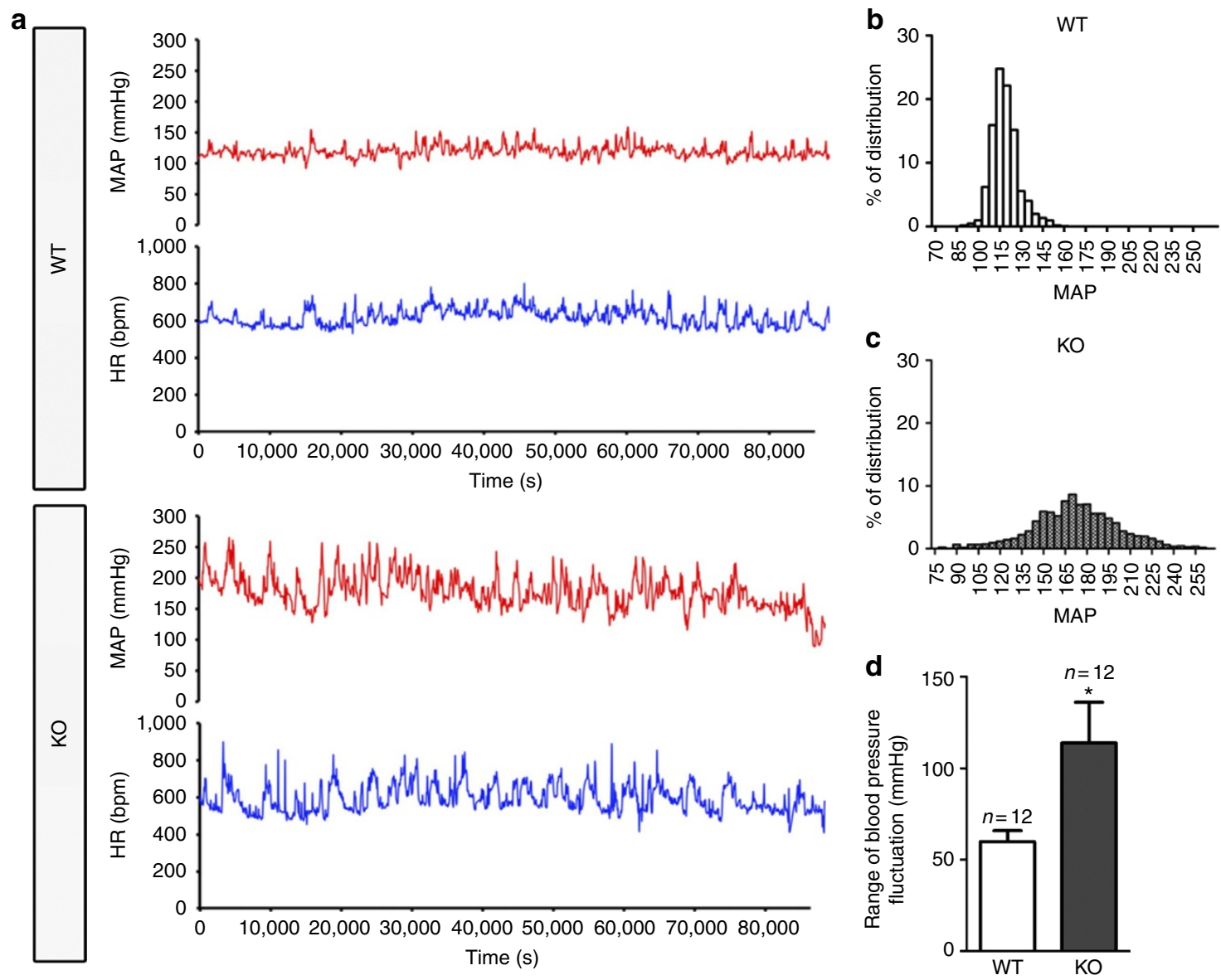

Figure 1 